\title{
KEANEKARAGAMAN BENALU DI ECOPARK, CIBINONG SCIENCE CENTER-BOTANIC GARDENS
}

\section{DIVERSITY OF MISTLETOES IN ECOPARK, CIBINONG SCIENCE CENTER-BOTANIC GARDENS}

\author{
Prima Wahyu K. Hutabarat*, Rizmoon Nurul Zulkarnaen, Melza Mulyani \\ Research Center for Plant Conservation and Botanic Gardens - Bogor Botanic Gardens, Indonesian Institute of \\ Sciences, Jl. Ir. H. Juanda No. 13 Bogor \\ *Corresponding author: hutabaratpwk@gmail.com
}

Naskah Diterima: 28 Januari 2020; Direvisi: 31 Maret 2019; Disetujui: 7 April 2020

\begin{abstract}
Abstrak
Area konservasi ex situ, Ecopark Cibinong Science Center-Botanic Gardens (CSC-BG), membutuhkan strategi pemeliharaan tanaman koleksi yang tepat untuk mendukung kesehatan dan keberlanjutan koleksinya. Serangan benalu atau tumbuhan parasit tidak hanya dapat merusak estetika, namun juga menghambat pertumbuhan dan perkembangan, bahkan membunuh tanaman koleksi. Penelitian ini bertujuan untuk mengetahui keanekaragaman jenis benalu dan distribusi spasial dari sebaran benalu di Ecopark CSC-BG. Pengumpulan spesimen dan data, meliputi jenis dan jumlah benalu, jenis dan kondisi inang, habitat menggunakan metode jelajah di seluruh area ini. Ditemukan empat jenis benalu dari suku Lorantaceae, yaitu Dendrophthoe pentandra (L.) Miq., Scurrula atropurpurea (Blume) Danser, Macrosolen cochinchinensis (Lour.) Tiegh., dan Dendrophthoe sp. Benalu tersebut tersebar di bioregion Blok 1, Jawa-Bali, Kalimantan, Sumatra, dan Papua. Beberapa faktor ekofisiologi yang disarankan untuk diperhatikan dalam distribusi benalu adalah tinggi inang, ekspos cahaya pada tajuk bagian atas inang, kepadatan tanaman koleksi, keterbukaan atau ekspos cahaya matahari pada habitat. Indeks keanekaragaman (H') dan indeks kemerataan (E') benalu yang ditemukan menunjukkan $H^{\prime}=1,29$ dan $E^{\prime}=0,93$. Hasil analisis pola spasial, keberadaan benalu relatif merata di seluruh bagian Ecopark CSC-BG, dengan keragaman jenis tertinggi berada di bioregion Jawa-Bali, Sumatra, dan Kalimantan. Kesimpulan penelitian ini 4 jenis benalu yang ditemukan di Ecopark CSC-BG dengan nilai indeks keanekaragaman jenis benalu tergolong sedang dengan pola sebaran merata.
\end{abstract}

Kata kunci: Benalu; Ecopark; Inang; Loranthaceae; Tumbuhan parasit

\begin{abstract}
The relevant information of existing mistletoes or parasitic plants in Ecopark-Cibinong Science Center \& Botanic Gardens is needed to support the plant collection maintenance strategy. The attack of mistletoes does not only inflict the aesthetic values of the collection but also inhibits the growth and possibly kills the whole plant. This research aimed to know the mistletoes species diversity and spatial distribution in the garden. The exploration method was used to collect specimens and data, included the species and number of mistletoes, the host and its condition, habitat and location. Four species of Loranthaceae attacked the plant collection in bioregion Blok 1, Jawa-Bali, Sumatra dan Kalimantan. They were Dendrophthoe pentandra (L.) Miq., Scurrula atropurpurea (Blume) Danser, Macrosolen cochinchinensis (Lour.) Tiegh. and Dendrophthoe sp.. Some of the recommended ecophysiological factors to consider in the distribution of mistletoes in Ecopark, CSC-BG were host height, light exposure to the upper canopy of the host, plant collection density, openness, or exposure to sunlight in the habitat. The diversity index ( $H$ ') and evenness index ( $\left.E^{\prime}\right)$ of mistletoes found in Ecopark CSC-BG were 1.29 and 0.93, respectively. Based on the results of spatial pattern analysis, the presence of mistletoes was relatively evenly distributed throughout the garden, with the highest species diversity found in the Java-Bali, Sumatra, and Kalimantan Bioregions. This study concludes that there were 4 species of mistletoes found in Ecopark CSC-BG with a moderate diversity index and an even distribution pattern.
\end{abstract}

Keywords: Ecopark; Host, Lorantahceae; Mistletoes; Parasitic plants

Permalink/DOI: http://dx.doi.org/10.15408/kauniyah.v13i2.15112 


\section{PENDAHULUAN}

Benalu atau tumbuhan parasit dapat tumbuh di berbagai ekosistem pada inang yang bervariasi. Benalu dapat diklasifikasikan berdasarkan proses pembentukan zat makanannya, yaitu holoparasit dan hemiparasit (Quested, 2008). Holoparasit merupakan benalu yang hampir tidak atau tidak memiliki klorofil, tidak berfotosintesis, dan sangat bergantung pada inangnya untuk memperoleh air dan nutrisi. Hemiparasit adalah benalu yang memiliki klorofil dan mampu berfotosintesis (Nickrent, 2002). Air, karbon, serta nutrisi lainnya yang dibutuhkan benalu jenis hemiparasit didapatkan dari tumbuhan inangnya melalui suatu jembatan fisiologis yang disebut haustorium. Benalu dapat mengganggu pertumbuhan, alometri serta reproduksi tumbuhan inangnya. Gangguan tersebut pada akhirnya tidak hanya akan berimplikasi pada struktur komunitas tumbuhan, zonasi vegetasi, dan dinamika populasi (Press \& Phoenix, 2005) namun juga memengaruhi produktivitas tumbuhan yang benilai ekonomis serta hasil hutan (Rist, Uma, \& Ghazoul, 2011).

Keberadaan benalu pada tanaman koleksi di kawasan konservasi ex situ seperti Taman Hutan Raya dan Kebun Raya dapat mengakibatkan kemunduran pertumbuhan dan memengaruhi kualitas kesehatan tanaman (Sunaryo, 1998; Sunaryo, Rachman, \& Uji, 2006). Studi mengenai benalu pada tanaman koleksi di Kebun Raya Purwodadi, Jawa Timur pada tahun 1995, 1999, dan 2006 menemukan adanya lima jenis benalu, yaitu Dendrophthoe pentandra, Macrosolen tetragonus, Scurrula atropurpurea, Viscum articulatum, dan V. ovalifolium (Uji, Sunaryo, \& Rachman, 2006). Uji, Sunaryo, dan Rachman (2007) melaporkan juga serangan empat jenis benalu di Kebun Raya Eka Karya Bali, yaitu Dendrophthoe pentandra (L.) Miq., Helixanthera cylindrical (Jack) Dans., Scurrula atropurpurea (Blume) Dans., dan Scurrula parasitica L.

Ecology park (ecopark) di kawasan Cibinong Science Center and Botanic Gardens (CSC-BG) merupakan salah satu kawasan konservasi ex situ tumbuhan seluas 32 ha berlokasi di Kecamatan Cibinong, Kabupaten Bogor pada ketinggian 165 mdpl. Sampai saat ini, pengelolaan Ecopark masih berada di bawah manajemen Pusat Penelitian Konservasi
Tumbuhan dan Kebun Raya-LIPI/Kebun Raya Bogor (KRB) (Ariati, Astuti, \& Ruspandi, 2018). Ecopark dibangun untuk melengkapi fasilitas ilmiah di kawasan CSC-BG yang dimanfaatkan tidak hanya untuk konservasi dan penelitian, tetapi juga untuk peningkatan wawasan masyarakat akan keanekaragaman hayati dan lingkungan. Koleksi tanaman yang didesain untuk mewakili flora hutan hujan tropis dataran rendah dari pulau-pulau besar di Indonesia. Tanaman koleksi ditata dalam area koleksi yang terbagi sedemikian rupa berdasarkan tujuh bioregion yaitu Sumatra, Jawa-Bali, Nusa Tenggara, Kalimantan, Sulawesi, Maluku, dan Papua (Noviady \& Rivai, 2015; Imron, Chodiq, \& Amas, 2016; Ariati et al., 2018). Koleksi tanaman di Ecopark tahun 2015 berjumlah 7.348 spesimen (Noviady \& Rifai, 2015). Namun, berdasarkan katalog terbaru tahun 2018, terdapat 6.105 spesimen yang tergolong ke dalam 86 suku, 328 marga, dan 733 jenis (Ariati et al., 2018).

Beberapa penelitian bidang botani di lingkungan ecopark telah banyak dilakukan, antara lain variasi serapan $\mathrm{CO}_{2}$ jenis-jenis pohon terkait potensi mitigasi gas rumah kaca (Hidayati, Mansur, \& Juhaeti, 2013), studi taksonomi Diospyros (Putri \& Chikmawati, 2015), studi kesehatan pohon peneduh (Noviady \& Rivai, 2015), keanekaragaman lumut kerak (Boerdeaux, 2015), desain ekologis taman koleksi pakis berbasis sistem klasifikasi bioregion (Nafar \& Gunawan, 2017), studi input hara dari serasah atau nekromasa (Kintamani, Yulizah, \& Rahajoe, 2017), inventarisasi jenis-jenis bambu (Damayanto, Mulyani, \& Wahidah, 2019) dan identifikasi hama dan penyakit tanaman di ecopark (Muttaqin, Hartantri, Meiganati, \& Hidayat, 2019). Penelitian tersebut umumnya memiliki tujuan atau dampak dalam meningkatkan kualitas koleksi dan lingkungan di ecopark, baik melalui inventarisasi, identifikasi potensi, dan rekomendasirekomendasi untuk manajemen koleksi.

Inventarisasi benalu pada tanaman koleksi di ecopark belum pernah dilakukan dan dipelajari semenjak ecopark didirikan tahun 2002, sehingga diperlukan data dan informasi keanekaragaman jenis benalu, kelimpahan, jenis inang, kondisi inang, dan lokasi persebaran benalu di kawasan Ecopark. Penelitian 
ini bertujuan untuk mengetahui keanekaragaman jenis benalu dan mengetahui distribusi spasial dari sebaran benalu di Ecopark CSC-BG. Penelitian ini diharapkan menjadi referensi pihak manajemen dalam kegiatan pemeliharaan tanaman koleksi dan upaya pengendalian populasi benalu di ecopark.

\section{MATERIAL DAN METODE}

Penelitian dilakukan di kawasan Ecopark CSC-BG, Kabupaten Bogor, Jawa Barat (Gambar 1). Secara geografis, lokasi penelitian terletak pada $106^{\circ} 51^{\prime} 06.82^{\prime \prime} \mathrm{BT}-106^{\circ}$ 51'17.52"BT dan 6²9'30.72”LS6²9'30.70'LS. Waktu penelitian dilaksanakan pada bulan April tahun 2016.

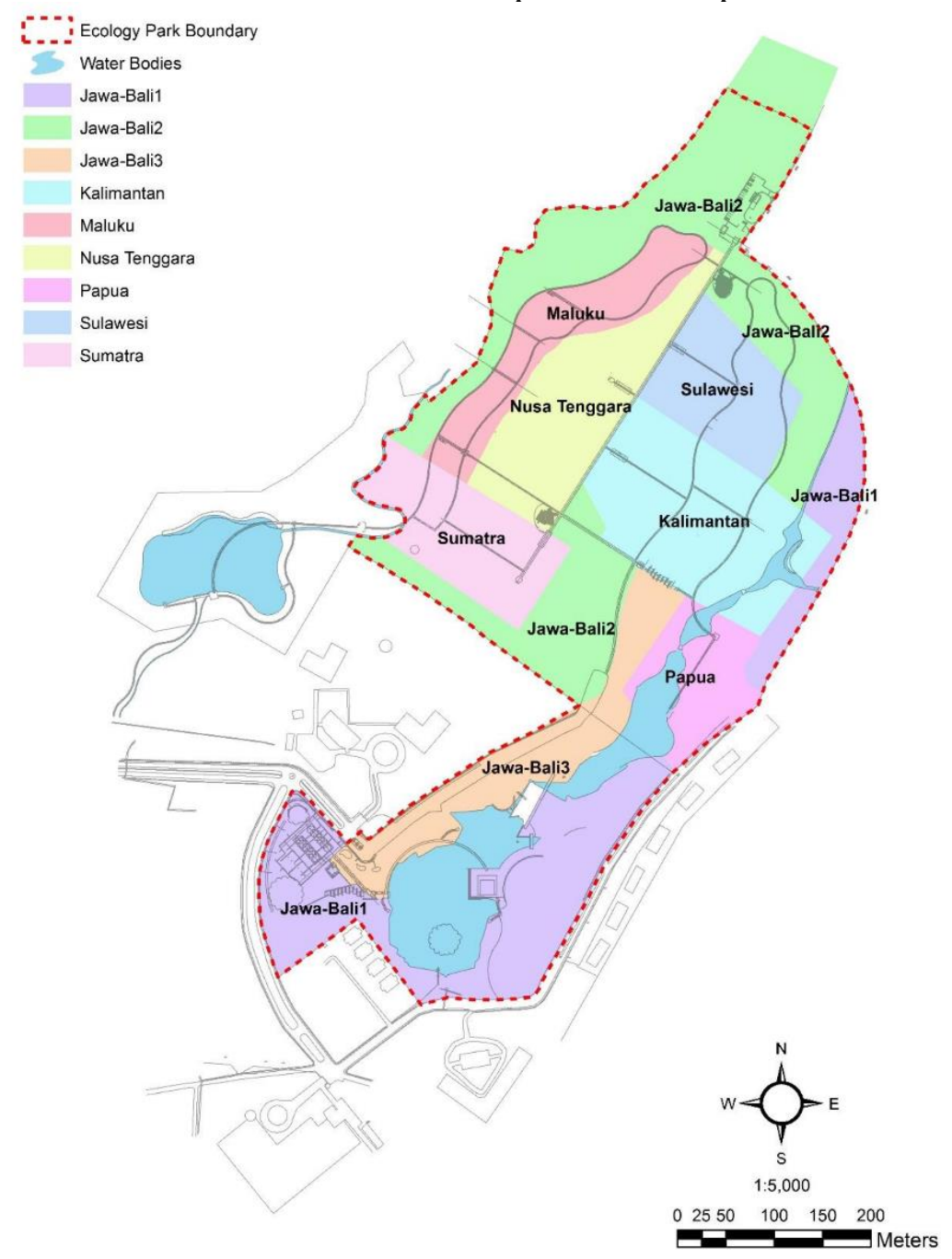

Gambar 1. Lokasi penelitian dan peta region Ecopark Cibinong Science Center and Botanic Gardens (Sumber: Ariati et al., 2018)

Metode penelitian menggunakan metode jelajah (Rugayah, Widjaja, \& Praptiwi, 2004) yaitu menjelajahi secara acak di semua blok atau bioregion di kawasan Ecopark, CSC-BG, dan mengoleksi voucher atau sampel benalu yang dijumpai pada tanaman inang. Pengkoleksian sampel benalu diikuti dengan pencatatan informasi penunjang seperti nomor koleksi, kolektor, tanggal koleksi, titik koordinat, lokasi, habitat, jenis tanaman inang, habitus inang, tinggi inang dan jumlah individu benalu dalam satu inang. Tanaman inang dinilai melalui pengamatan visual dengan kriteria-kriteria tertentu (Tabel 1). Identifikasi sampel tanaman dilakukan dengan bantuan Flora of Java (Backer \& Bakhuizen van den Brink, 1965) dan Flora Malesiana (Barlow, 1997; Nooteboom et al., 2016). Validasi identifikasi jenis juga dilakukan dengan menggunakan acuan spesimen herbarium di Herbarium Bogoriense (BO). Terminologi morfologi mengacu pada Glosarium Biologi (Rifai \& Puryadi, 2008). Kunci identifikasi tingkat jenis disusun berdasarkan deskripsi morfologi setiap jenis benalu. 
Tabel 1. Kriteria penilaian kondisi tanaman inang

Kondisi kerapatan tajuk Kesehatan tanaman inang

Tajuk rapat (>75\%), daun sabagian besar hijau/ normal Baik

Tajuk sedang (50-75\%), daun sebagian kecil kekuningan atau kering

Tajuk renggang $(<50 \%)$, daun sebagian besar kekuningan atau kering

Penilaian nilai keanekaragaman $\left(\mathrm{H}^{\prime}\right)$ dan kemerataan (E') benalu di Ecopark, CSC-BG menggunakan Indeks Keanekaragaman Shannon-Wiener dan indeks kemerataan/evenness (Odum, 1994). Adapun rumus yang digunakan untuk penilaian nilai keanekaragaman adalah $\mathrm{H}^{\prime}=-\Sigma$ pi $\log _{2}$ pi dengan keterangan $H^{\prime}$ adalah indeks keragaman menurut Shannon-Wiener dan Pi merupakan proporsi spesies $i$ terhadap keseluruhan jumlah spesies yang dijumpai. Kemudian rumus yang digunakan untuk kemerataan adalah $E^{\prime}=H^{\prime} / \ln S$, yaitu indeks kemerataan merupakan hasil dari indeks keanekaragaman Shannon - Wienner dibagi logaritma natural jumlah spesies. Tingkat kemerataan komunitas dengan nilai $\mathrm{E}<0,4$ dikategorikan rendah, $0,4 \leq \mathrm{E} \leq 0,6$ merupakan kategori sedang dan nilai $E>0,6$ merupakan kategori tinggi.

Analisis deskriptif dengan menghitung kekayaan jenis (species richness) juga dilakukan untuk mengungkap jumlah jenis (Chao, 2005). Adapun analisis distribusi spasial penyebaran benalu menggunakan perangkat lunak DIVA-GIS (Hijmans, Cruz,
Rojas, \& Guarino, 2001). Analisa spasial yang dilakukan dengan membagi kawasan dalam grid berukuran 132 x $132 \mathrm{~m}$, kemudian dilakukan penghitungan tingkat keanekaragaman dan kekayaan jenis di masing-masing grid.

\section{HASIL \\ Inventarisasi Jenis Benalu}

Berdasarkan hasil survei di kawasan Ecopark, CSC-BG, ditemukan 4 jenis benalu dari suku Loranthaceae pada 10 jenis inang dari 7 suku dikotil, yaitu Apocynanceae, Anacardiaceae, Euphorbiaceae, Lauraceae, Malvaceae, Meliaceae, dan Moraceae (Tabel 2). Kemunculan individu benalu terbanyak ditemukan pada suku Euphorbiaceae, yaitu Macaranga sp., Mallotus paniculatus, dan Antidesma montanum (total 12 individu) dan suku Apocynaceae, yaitu Cerbera manghas dan Wrightia religiosa (total 10 individu). Jenis inang yang paling banyak diserang oleh benalu dalam satu individu inang adalah Mallotus paniculatus, Mangifera indica, dan Arthocarpus sp.

Tabel 2. Daftar jenis dan jumlah benalu, serta jenis, dan kondisi inang di Ecopark Cibinong Science Center and Botanic Gardens

\begin{tabular}{|c|c|c|c|c|c|c|c|}
\hline \multirow{2}{*}{ Jenis benalu } & \multirow{2}{*}{$\Sigma$} & \multicolumn{5}{|c|}{ Inang } & \multirow[t]{2}{*}{ Bioregion } \\
\hline & & Jenis & Suku & Habitus & Tinggi (m) & Kondisi & \\
\hline \multirow{4}{*}{$\begin{array}{l}\text { Dendrophthoe } \\
\text { pentandra (L.) } \\
\text { Miq }\end{array}$} & 1 & Cerbera manghas L. & Apocynacaeae & Pohon & 10 & Baik & Blok 1 \\
\hline & 7 & Mangifera indica $\mathrm{L}$ & Anacardiaceae & Pohon & 8 & Baik & Blok 1 \\
\hline & 1 & $\begin{array}{l}\text { Dysoxylum } \\
\text { gaudichaudianum } \\
\text { (A.Juss) Mia }\end{array}$ & Meliaceae & Pohon & 10 & Baik & Jawa Bali \\
\hline & 6 & Arthocarpus sp. 1 & Moraceae & Pohon & 4 & Buruk & Sumatra \\
\hline \multirow{4}{*}{$\begin{array}{l}\text { Macrosolen } \\
\text { cochinchinensis } \\
\text { (Lour.) Tiegh }\end{array}$} & 1 & Macaranga sp. & Euphorbiaceae & Pohon & 7 & Baik & Jawa Bali \\
\hline & 1 & $\begin{array}{l}\text { Litsea gracilis } \\
\text { Gamble }\end{array}$ & Lauraceae & Pohon & 9 & Baik & Kalimantan \\
\hline & 1 & Arthocarpus sp. 1 & Moraceae & Pohon & 4 & Buruk & Sumatra \\
\hline & 1 & Arthocarpus sp. 3 & Moraceae & Pohon & 4 & Baik & Sumatra \\
\hline \multirow{2}{*}{$\begin{array}{l}\text { Scurrula } \\
\text { atropurpurea } \\
\text { (Blume) Danser }\end{array}$} & 9 & $\begin{array}{l}\text { Mallotus paniculatus } \\
\text { (Lam) Mull.Arg }\end{array}$ & Euphorbiaceae & Pohon & 10 & Baik & Kalimantan \\
\hline & 1 & $\begin{array}{l}\text { Pterocymbium } \\
\text { javanicum } \mathrm{R} . \mathrm{Br}\end{array}$ & Malvaceae & Pohon & 10 & Baik & Jawa Bali \\
\hline
\end{tabular}




\begin{tabular}{|c|c|c|c|c|c|c|c|}
\hline \multirow{2}{*}{ Jenis benalu } & \multirow{2}{*}{$\Sigma$} & \multicolumn{5}{|c|}{ Inang } & \multirow[t]{2}{*}{ Bioregion } \\
\hline & & Jenis & Suku & Habitus & Tinggi (m) & Kondisi & \\
\hline \multirow[t]{4}{*}{$\begin{array}{l}\text { Dendrophthoe } \\
\text { sp. }\end{array}$} & 2 & $\begin{array}{l}\text { Antidesma } \\
\text { montanum Blume }\end{array}$ & Euphorbiaceae & Perdu & 2 & Sedang & Kalimantan \\
\hline & 2 & $\begin{array}{l}\text { Wrightia religiosa } \\
\text { (Teijism \& Binn) } \\
\text { Benth.ex Kurz }\end{array}$ & Apocynacaeae & Perdu & 1 & Buruk & Papua \\
\hline & 4 & $\begin{array}{l}\text { Wrightia religiosa } \\
\text { (Teijism \& Binn) } \\
\text { Benth.ex Kurz }\end{array}$ & Apocynacaeae & Perdu & 2 & Baik & Jawa Bali \\
\hline & 4 & $\begin{array}{l}\text { Wrightia religiosa } \\
\text { (Teijism \& Binn) } \\
\text { Benth.ex Kurz }\end{array}$ & Apocynacaeae & Perdu & 2 & Baik & Jawa Bali \\
\hline
\end{tabular}

\section{Deskipsi dan Kunci Identifikasi Jenis Benalu di Ecopark}

Empat jenis benalu yang ditemukan di Ecopark, CSC-BG berasal dari suku Loranthaceae, yaitu Dendrophthoe pentandra (L.) Miq., Scurrula atropurpurea (Blume) Danser, Macrosolen cochinchinensis (Lour.) Tiegh. (Gambar 2) dan Dendrophthoe sp. (Gambar 3). Berikut adalah kunci identifikasi untuk membedakan empat jenis tersebut:

1.a. Bentuk daun menjorong, melonjong, atau bundar telur sungsang .............2

b. Bentuk daun melanset.............Dendrophthoe sp.*

2.a. Daun gagang (bract) satu.............. 3

b. Daun gagang (bract) lebih dari satu, 1 atau 2 pasang.

Macrosolen cochinchinensis

3.a. Tabung mahkota menggembung dan kemerahan, organ muda tanpa indumentum...Dendrophthoe pentandra

b. Tabung mahkota tidak menggembung, organ muda tertutup indumentum keabuan berbentuk bintang

Keterangan:

..................Scurrula atropurpurea

* = kondisi Dendrophthoe sp. masih tergolong muda, sehingga kemungkinan akan mengalami perubahan kunci atau nama spesies di kemudian hari

Dendrophthoe pentandra (L.) Miq., Fl. Ind. Bat. 1,1 : 818 (1856); Backer \& Bakhuizen van den Brink, f. Fl. Java 2 : 72 (1965); Barlow, B.A., Fl. Malesiana. Ser. I, 13: 318 (1997); Huaxing et al., Fl. China 5: 220-239 (2003) Loranthus pentandrus Linnaeus, Syst. Nat., ed.
12, 2: 252. 1767; Mant. Pl. 1: 63. 1767. Tipe: Anon. s.n. (LINN).

Perdu, hemiparasit, 50-150 cm; batang keabu-abuan dengan banyak lentisel; daun tersusun spiral, tersebar atau sebagian seperti berhadapan (subopposite) (Gambar 2a), bentuk daun menjorong atau melonjong, 6-13 cm x $1,5-8 \mathrm{~cm}$, ujung daun meruncing sampai membulat, pangkal daun meruncing atau melancip, tangkai daun 5-20 mm, warna abaksial lebih terang daripada adaksial, urat daun nampak dari sisi atas dan bawah, urat daun primer terkadang berwarna kemerahan, urat daun sekunder berhadapan; perbungaan tandan (Gambar 2b), 10-35 mm, 6-12 bunga; bunga biseksual, 13-25 mm, membuyung, bagian bawah saling berpautan dan menyempit di bagian atas membentuk leher atau menggada, daun gagang satu; mahkota 4-5 merus, mencorong, warna ujung mahkota mula-mula hijau kemudian hijau kekuningan kemudian menjadi kuning atau merah oranye, tabung mahkota 6$12 \mathrm{~mm}$, kemerah-merahan; benang sari 5, 2-5 $\mathrm{mm}$, kepala sari melekat pada bagian pangkal (basifik); buah bulat telur, panjang $10 \mathrm{~mm}$ dan lebar $6 \mathrm{~mm}$; biji tunggal ditutupi oleh lapisan bertekstur lengket.

Distribusi: India bagian timur sampai Indocina, Semenanjung Malaya, Singapura, Sumatra, Borneo, Jawa, Bali, Nusa Tenggara dan Filipina (Barlow, 1997; Huaxing, Huahsing, Hua-xing, \& Gilbert, 2003).

Habitat dan ekologi: Hutan hujan yang lembap, hutan terbuka atau perkebunan, umum di dataran rendah sampai $500 \mathrm{mdpl}$, jarang sampai di ketinggian $1.650 \mathrm{mdpl}$. Sangat umum, tumbuh pada banyak jenis pohon dan 
semak (Backer \& Bakhuizen van den Brink, 1965; Barlow, 1997; Huaxing et al., 2003).

Spesimen yang diamati: Borneo: Pulau Penebangan, Kalimantan Barat, 20/03/1931, Mondi 108 (BO); TN Gunung Palung, Ketapang, Kalimantan Barat, 03/03/1997, TL 566 (BO); Jawa: Plantantuin Buitenzorg, Bogor, Jawa Barat, 03/05/1927, Van Leeuwen s.n. (BO); Nongkojajar, Pasuruan, jawa Timur, 30/10/1919, Bremekamp s.n. (BO); TN Karimunjawa, Jawa Tengah, 06/05/2005, TD 604 (BO); Pasar minggu, Jakarta Selatan, 16/02/1927, OCHSE 14 (BO); New Guinea: Hubikosi Dist., Wamena, Jayawijaya, Papua,

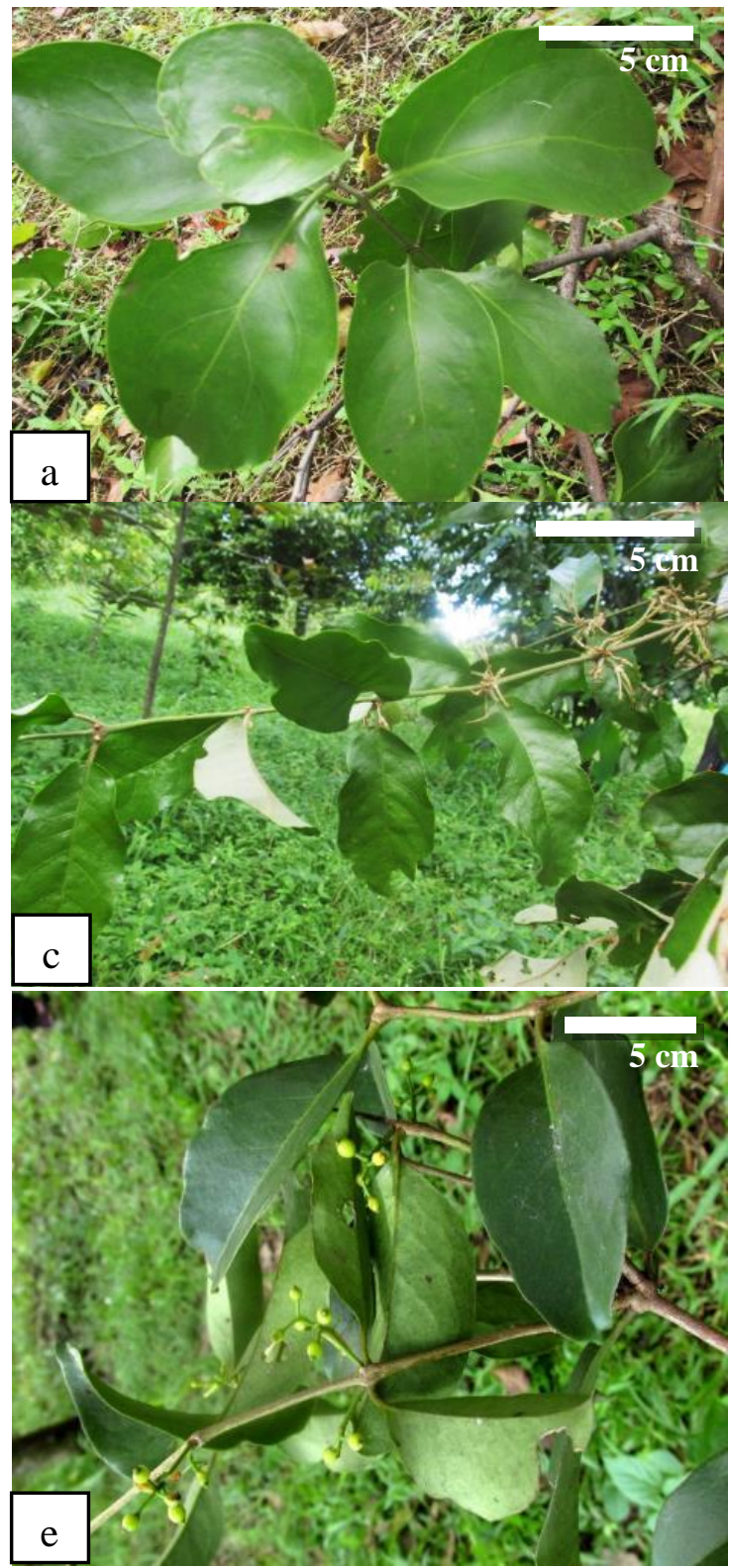

17/04/2018, LSJ 1989 (BO); Sumatra: G. Lengkudu, Aceh tenggara, 01/03/1980/, SP 2627 (BO); Harapan rain forest, Jambi, 03/03/2013, BOHK 403 (BO); Pulau Karimun, Kep. Riau, 23/04/2017, IPGPD 296 (BO).

Etimologi: Dendrophthoe berasal dari dua kata dari bahasa Yunani yaitu dendro yang berarti pohon (Stearn, 2004) dan phthio yang berarti menurun, merusak, atau mengonsumsi, sehingga mengacu pada sifat parasit yang merusak pohon atau inang. Pentandra atau pentandrus berarti lima benang sari (Stearn, 2004), mengacu pada jumlah benang sari yaitu lima.

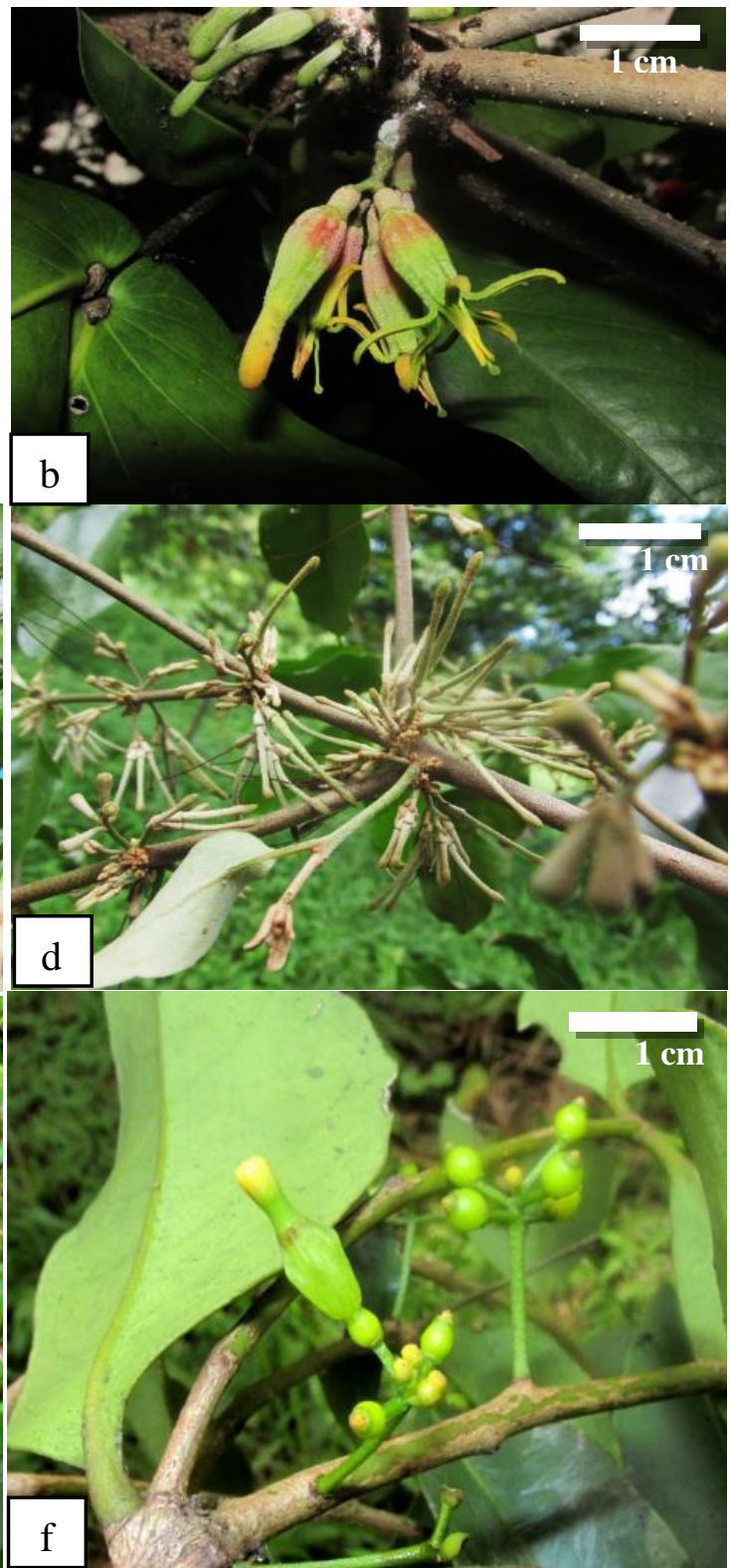

Gambar 2. Karakter morfologi: bentuk daun Dendrophthoe pentandra (L.) Miq. (a), bunga Dendrophthoe pentandra (L.) Miq. (b), bentuk daun Scurrula atropurpurea (Blume) Danser (c), bunga Scurrula atropurpurea (Blume) Danser (d), bentuk Macrosolen cochinchinensis (Lour.) Tiegh. (e), bunga Macrosolen cochinchinensis (Lour.) Tiegh. (f). 
Scurrula atropurpurea (Blume) Danser, Bull. Jard. Bot. Buitenzorg III, 10 (1929) 349; 11 (1931) 429; Backer \& Bakhuizen van den Brink. f., Fl. Java 2 (1965) 74; Barlow, Blumea 36 (1997) 70. - Loranthus atropurpureus Blume, Verh. Bat. Genootsch. 9 (1823) 186 Isotipe: Blume s.n. (L)

Perdu, hemiparasit, 70-100 cm; batang keabu-abuan, permukaan halus dan lentisel tersebar; daun berhadapan (Gambar 2c), menjorong atau membundar telur sungsang, 5$10 \times 2,5-5 \mathrm{~cm}$, ujung daun menumpul atau membundar, pangkal daun memiliki bentuk meruncing atau membundar, tangkai daun 5$12 \mathrm{~mm}$, urat daun tidak nyata kecuali pada urat daun primer, lamina relatif tipis, adaksial gundul mengkilat, abaksial gundul keabuan; perbungaan tandan pada ketiak daun (Gambar 2d), 2-8 bunga; bunga biseksual, panjang tangkai bunga 2-3 mm, daun gagang 1, kelopak membuyung berbentuk tabung 2,5-3,5 $\mathrm{mm}$; mahkota bunga panjang berbentuk tabung 7-15 mm, ujung menggada dan meruncing; kepala sari melekat pada pangkal atau basifik, $1 \mathrm{~mm}$; buah bulat telur sungsang atau seperti gada, 8-9 mm. Biji tunggal ditutupi oleh lapisan lengket; pada pucuk daun, daun muda, dan bunga muda ditutupi rambut-rambut berbentuk bintang (stellate hairs) yang padat berwarna kuning gading atau abu-abu dan menjadi jarang setelah dewasa.

Distribusi: China bagian selatan, Vietnam, Thailand, Malaysia, Filipina, Jawa, Nusa Tenggara, dan Maluku (Barlow, 1997; Huaxing et al., 2003).

Habitat dan Ekologi: Dataran rendah (0-600 mdpl), lereng hutan pegunungan (sampai $2.900 \mathrm{mdpl}$ ) tumbuh pada berbagai inang, Acacia, Averrhoa, Grewia, Myristica, and Terminalia (Backer \& van den Brink, 1965; Barlow, 1997; Huaxing et al., 2003).

Spesimen yang diamati: Jawa: Buitenzorg, Jawa Barat, 26/02/1927, Danser 6648 (BO); Jember, Jawa Timur, 1918, Ultei 1 (BO); Buitenzorg, Jawa Barat, 18/11/1930, Eaust 9 (BO); Gn. Kencana, Lebak Kidul, Banten, 13/06/1912, Koorders 41291 (BO);

Sunda Kecil: Baturiti, Bali, 14/06/1929, Ruttner 331 (BO); Air terjun Jeruk Nanis, Lombok, 16/02/2005, Azuma et al. A269 (BO).

Etimologi: Scurrula atau scurra adalah bahasa latin yang berarti badut kecil
(Quattrocchi, 2012). Penamaan ini dimungkinan mengacu bentuk perbungaan marga ini yang menyerupai topi badut. Atropurpurea berasal dari dua kata ater dan purpureus yang berarti ungu tua (Stearn, 2004), kemungkinan mengacu pada warna tangkai sari yang berwarna ungu gelap kemerahan.

Macrosolen cochinchinensis (Lour.) Tiegh., Bull. Soc. Bot. France 41 (1894) 122; Backer \& van den Brink. f., Fl. Java 2 (1965) 69. Loranthus cochinchinensis Lour., Fl. Coch. (1790) 195. - Tipe: tidak diketahui.

Perdu, hemiparasit, $50-130 \mathrm{~cm}$, bercabang banyak; batang keabu-abuan, lentisel tersebar; daun berhadapan-berseling atau spiral (Gambar 2e), menjorong, 4-16 x 2$7 \mathrm{~cm}$, ujung daun meruncing, kadang membundar, pangkal daun selalu meruncing, tangkai daun 1-10 mm adaksial hijau muda gundul, abaksial lebih muda dan pucat, urat daun primer nyata di kedua sisi; Perbungaan tandan (Gambar 2f), atau payung (subumbullate), 2-7 pasang, bunga berpasangan dan berhadapan; bunga biseksual, 5$20 \mathrm{~mm}$, tangkai bunga $0-6 \mathrm{~mm}$, daun gagang 1-2 pasang, berbentuk segitiga, kelopak membuyung; Mahkota berbentuk tabung, 9-15 $\mathrm{mm}$, bagian bawah hijau kekuningan, ujung kuning atau merah, leher coklat atau merah tua. Buah berwarna hijau sampai kuning tua, agak bulat atau bulat telur sungsang; biji tunggal ditutupi oleh lapisan yang lengket.

Distribusi: Asia Selatan (India, Nepal), Cina bagian selatan, Indocina (Thailand, Vietnam, Myanmar), Malesia (Peninsular Malaysia, Indonesia sampai New Guinea) (Barlow, 1997; Huaxing et al., 2003).

Habitat \& Ekologi: Hutan lembap dan terbuka, area datar atau terganggu, lembah dan lereng gunung, pada ketinggian 100-1.600 mdpl. Sangat umum tumbuh di dataran rendah namun ditemukan juga pada ketinggian 2.270 mdpl. Tumbuh pada banyak jenis inang (Barlow, 1997; Huaxing et al., 2003).

Spesimen yang diamati: Borneo: Gn. Berui, Kalimantan Barat, 25/10/1995, KYT K10561 (BO); Kota Waringin Lama, Pangkalanbun, Kalimantan Tengah, 01/07/1998, B-42 (BO); Kutai Barat, Kalimantan Timur, 12/10/1925, Endert 3894 
(BO); Jawa: Hortus Bogoriense, Bogor, Jawa Barat, 07/11/1952, Meijer 1300 (BO); Tasikmalaya, Jawa Barat, 28/07/1917, Koorders 327 (BO); Gn. Kencana, Lebak Kidul, Banten, 12/06/1912, Koorders 40987 (BO); Buitenzorg, Jawa Barat, 26/01/1927, Danser 6636 (BO); Sunda Kecil: Flores Barat, Nusa Tenggara Timur, 06/05/1965, Konsterman \& Wirawan 803 (BO); Peninsular Malaysia: Tampin, Negeri Sembilan, Malaysia, 24/08/1926, Burckill 2211 (BO); Maluku: Kali Doworo Ina, Halmahera, Maluku Utara, 26/09/1974, Vogel 3120 (BO); New Guinea: Hubikosi, Gunung Susu, Jayawijaya, Papua, 01/05/2014, Juswara \& Wardi 896 (BO); Philippines: Cavite, Luzon,01/04/1915/, Ramos \& Deroy 22568 (BO); Sumatra: Fort de Kock, Bukittinggi, Sumatra Barat, 01/11/1931, Jacobson 140 (BO).
Etimologi: Macrosolen berasal dari dua kata bahasa Yunani, makros yang berarti besar, dan solen yang berarti tabung (Stearn, 2004), mengacu pada bentuk mahkota tabung. Cochinchinensis berasal dari Cochin-China, nama lama daerah di Selatan Vietnam, yang kemungkinan diambil dari asal lokasi spesimen pertama yang dideskripsikan.

\section{Dendrophthoe sp.}

Perdu, hemiparasit, tinggi $10-30 \mathrm{~cm}$, bercabang dari dasar; batang abu-abu atau kemerahan; daun spiral atau tersebar (Gambar 3), melanset, 4,5-8 x 1-4 cm, ujung daun meruncing, melancip, kadang membulat, pangkal daun meruncing, adaksial hijau muda gundul, mengkilap, abaksial lebih muda dan pucat, tangkai daun $1-10 \mathrm{~mm}$, urat daun primer nyata di kedua sisi, berwarna kemerahan pada abaksial.

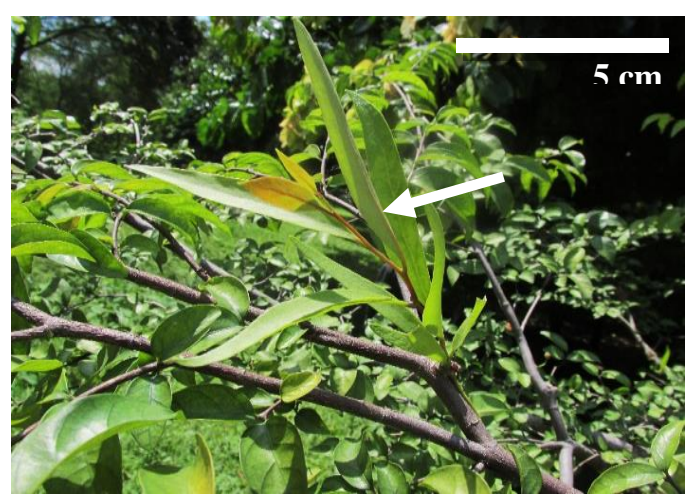

Gambar 3. Daun Dendrophthoe sp.

Habitat \& Ekologi: Dataran rendah 165 mdpl, pada area terbuka. Tumbuh pada inang pohon kecil atau semak dengan tajuk yang jarang.

Spesimen Dendrophthoe sp. tidak memiliki organ generatif saat dikoleksi sehingga identifikasi pada tingkat jenis sulit untuk dilakukan. Berdasarkan ukuran benalu yang kecil, jumlah daun dan percabangan tajuk yang sedikit, spesimen ini diasumsikan berumur muda. Berdasarkan karakter vegetatif, yaitu posisi daun yang spiral atau tersebar, urat daun jelas di kedua sisi, tangkai daun yang relatif pendek dan urat daun dan tangkai daun yang kemerahan, lebih mendekati karakter marga Dendrophthoe.

\section{Indeks Keanekaragaman Benalu di Ecopark CSC-BG}

Hasil analisis keanekaragaman ( $\left.\mathrm{H}^{\prime}\right)$ dan kemerataan (E') benalu yang ditemukan di Ecopark CSC-BG menunjukkan hasil $\mathrm{H}^{\prime}=$ 1,29 dan $E^{\prime}=0,93$. Hasil indeks keanekaragaman yang diperoleh tersebut mengindikasikan bahwa secara komunitas menunjukkan kondisi yang stabil $\left(\mathrm{H}^{\prime}=1-2\right)$, sedangkan secara tingkat keanekaragaman menunjukkan nilai yang rendah (Odum, 1994). Hal tersebut diketahui juga dari inventarisasi benalu yang dilakukan (Tabel 2) hanya ditemukan 4 jenis dengan 41 individu di seluruh area Ecopark CSC-BG. Kondisi yang berbeda ditunjukan pada perhitungan analisa indeks kemerataan jenis yang menunjukan nilai e' $=0,93$. Nilai tersebut mengindikasikan bahwa kemerataan benalu di Ecopark CSC-BG tergolong tinggi ( $\left.E^{\prime}>0,6\right)$ (Odum, 1994).

\section{Analisis Pola Spasial}


Hasil dari analisa pola spasial keanekaragaman jenis benalu dapat dilihat pada Gambar 4a. Dari gambar tersebut dapat diketahui bahwa benalu menyebar di seluruh area Ecopark CSC-BG dengan tingkat keanekaragaman yang terbagi menjadi 2 kelompok indeks, yaitu 0,8-1,0 (warna merah) dan 0,0-0,2 (warna hijau tua) (Hijmans, Cruz, Rojas, \& Guarino, 2001). Tiga grid yang memiliki nilai indeks keanekaragaman tinggi (grid merah) yaitu 1 grid bioregion Jawa-Bali, 1 grid gabungan bioregion Sumatra dan JawaBali dan 1 grid pada gabungan bioregion Kalimantan \& Jawa-Bali, sedangkan nilai indeks keanekaragaman rendah ( $g r i d$ hijau tua) yaitu 2 grid pada bioregion Jawa-Bali, 1 grid pada gabungan bioregion Nusa Tenggara, Sulawesi, dan Kalimantan, 1 grid pada Blok 1,

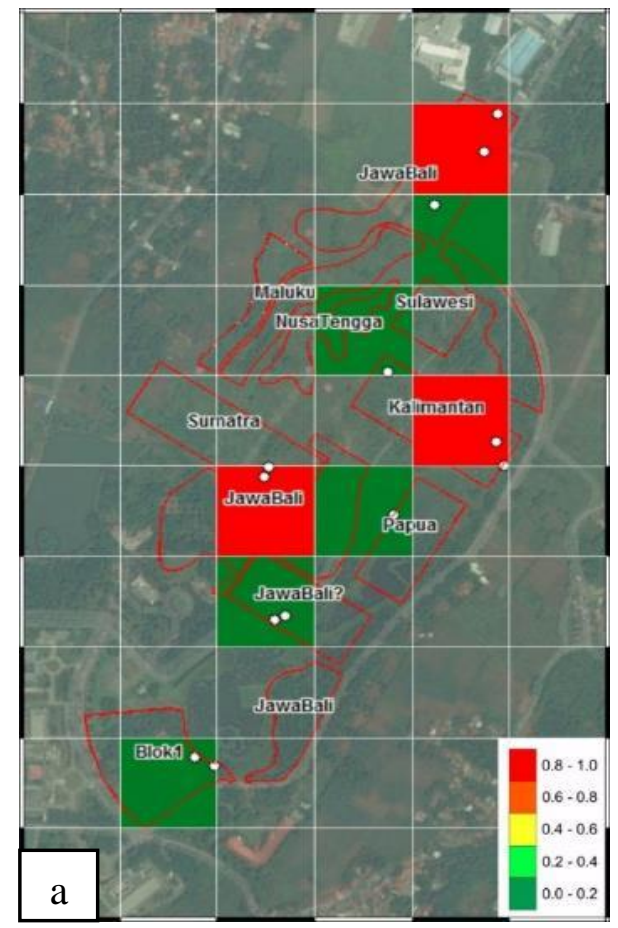

Gambar 4. Pola spasial benalu di Ecopark Ecopark Cibinong Science Center and Botanic Gardens keanekaragaman jenis (a) dan kekayaan jenis (b).

\section{PEMBAHASAN}

Empat jenis benalu yang teridentifikasi di area Ecopark CSC-BG, Dendrophthoe pentandra, Scurrula atropurpurea, Macrosolen cochinchinensis, dan Dendrophthoe sp. termasuk ke dalam suku Loranthaceae. Sebagian besar suku Loranthaceae tersebar di daerah tropis dan daerah temperate bagian selatan (Barlow, 1997; Huaxing et al., 2003). Dendrophthoe pentandra dan Scurrula atropurpurea

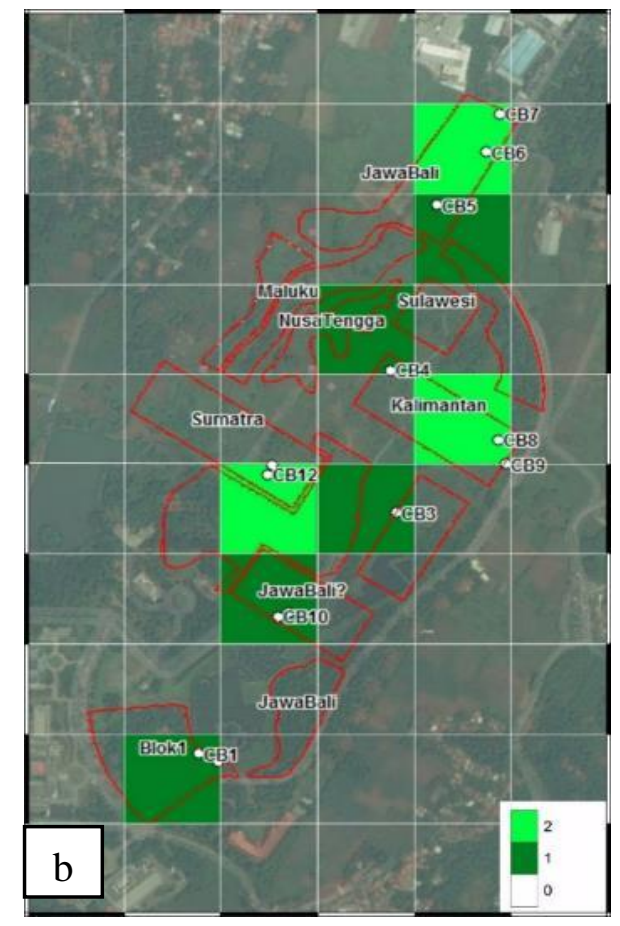

1 grid pada gabungan bioregion Papua dan Jawa-Bali.

Dengan metode yang sama, analisis densitas spasial untuk kekayaan spesies benalu ditunjukkan pada Gambar 4b. Serupa dengan hasil analisis pola spasial keanekaragaman jenis, terdapat 3 grid yang memiliki indeks kekayaan jenis benalu bernilai 2 yaitu 1 grid bioregion Jawa-Bali, 1 grid gabungan bioregion Sumatra dan Jawa-Bali dan 1 grid pada gabungan bioregion Kalimantan \& JawaBali, nilai indeks kekayaan jenis bernilai 1 terdapat pada grid-grid di gabungan antara bioregion Blok 1, Jawa-Bali, Papua, Nusa Tenggara, Kalimantan, dan Sulawesi, sedangkan grid lainnya, memiliki nilai indeks nol. Artinya, sebagia $\mathrm{n}$ besar grid pada wilayah Ecopark CSC-BG ini memiliki indeks kekayaan jenis bernilai nol atau 1 .

memiliki distribusi alami di Pulau Jawa, sedangkan Macrosolen cochinchinensis berasal dari China, namun sudah tersebar luas sampai ke Malesia (Barlow, 1997). Keberadaan jenisjenis benalu di Ecopark CSC-BG ternyata mempunyai kemiripan dengan jenis-jenis benalu yang ditemukan di beberapa Kebun Raya, antara lain Kebun Raya Baturraden (Sunaryo \& Uji, 2010) dan Kebun Raya Eka Karya Bali (Sunaryo et al., 2006). Jenis benalu yang mendominasi ditemukan di masing- 
masing Kebun Raya ternyata adalah $D$. pentandra. Fenomena ini dapat memberikan informasi bahwa daya adaptasi $D$. pentandra relatif tinggi dan berpotensi invasif.

Loranthaceae dikenal sebagai perdu hemiparasit yang menyerang pada batang atau akar pohon atau perdu tumbuhan dikotil dari berbagai suku (Nickrent, 2002; Uji et al., 2006; Uji et al., 2007). Dendrophthoe pentandra di Ecopark CSC-BG menjadi parasit pada jenis pohon atau perdu dari suku Apocynaceae, Anacardiaceae, Meliaceae, dan Moraceae. Pada studi di Kebun Raya Purwodadi, D. pentandra menjadi parasit pada 23 suku, khususnya pada suku Moraceae, Caesalpinaceae (Leguminosae) dan Rutaceae (Uji et al., 2006), sedangkan pada studi di Kebun Raya Eka Karya Bali, tanaman inang berasal dari 14 suku, khususnya pada suku Myrtaceae, Euphorbiaceae, dan Pittosporaceae (Uji et al., 2007). Dalam konteks asosiasi antara suatu jenis benalu dengan banyak jenis inang, maka dapat dikatakan $D$. pentandra adalah spesies generalis, yaitu spesies yang tidak memparasiti satu atau beberapa taksa spesifik. Hal ini didukung oleh Barlow (1997) yang menyatakan bahwa jenis ini banyak ditemukan pada inang dari beragam jenis dan suku.

Macrosolen cochinchinensis ditemukan pada tiga jenis suku di Ecopark CSC-BG, yaitu Euphorbiaceae, Lauraceae, dan Moraceae. Di daerah asalnya, China, $M$. cochinchinensis adalah spesies generalis karena menyerang banyak jenis inang, yaitu Castanea mollissima (Fag.), Cinnamomum camphora (Lau.), Cunninghamia lanceolata (Cup.), Ficus lacor (Mor), Liquidambar formosana (Alt.), Schima superba (Tea.), dan Vernicia montana (Eup.) (Huaxing et al., 2003). Seperti D. pentandra, $M$. cochinchinensis adalah spesies yang menyerang banyak jenis dikotil (Barlow, 1997).

Barlow (1997) mencatat Scurrula atropurpurea hanya menyerang lima marga, dari 5 suku tumbuhan, sedangkan Uji et al. (2007) yang menyatakan bahwa benalu jenis ini ditemukan pada dua jenis inang dari suku Malvaceae dan Actinidiaceae. Pada kasus di Ecopark CSC-BG, S. atropurpurea ditemukan pada dua jenis inang, Mallotus paniculatus (Eup.) dan Pterocymbium javanicum (Mlv.).
Selain itu, 9 individu benalu ditemukan menyerang pada satu individu inang $M$. paniculatus namun tidak ditemukan pada pohon lain di sekitarnya. Dendrophthoe sp. hanya terdapat di dua inang dengan habitus perdu dengan tinggi sekitar $2 \mathrm{~m}$, yaitu Wrightia religiosa dan Antidesma montanum yang tumbuh di area terbuka. Diduga jenis ini belum lama menyerang tanaman koleksi di Ecopark, CSC-BG, karena individu yang ditemukan relatif kecil dan belum memiliki organ reproduktif. Kecenderungan dua jenis benalu, $S$. atropurpurea dan Dendrophthoe sp., yang menyerang hanya beberapa atau sedikit jenis taksa, memunculkan hipotesis bahwa kemungkinan besar kedua jenis tersebut adalah spesies spesialis. Namun hipotesis ini perlu dibuktikan dengan penelitian dengan sampel yang lebih banyak dan luas.

Beberapa hipotesis muncul dalam menjawab faktor yang memengaruhi asosiasi atau interaksi antara benalu dan inangnya (Barlow \& Wiens, 1977; Atsatt, 1983; Ehleringer et al., 1986; Glatzel \& Geils, 2009), namun pendekatan eko-fisiologi dinilai paling mendukung (Canyon \& Hill, 1997; Glatzel \& Geils, 2009) dibandingkan pendekatan morfologi atau biosistematik. Pada studi ini, melalui observasi singkat pada voucher herbarium yang diperoleh, ditemukan sedikit kemiripan bentuk daun secara umum antara $D$. pentandra atau $M$. cochinchinensis dengan inang-inangnya, sedangkan kemiripan daun benalu dan inangnya pada $S$. atropurpurea atau Dendrophthoe sp. dengan inang-inangnya dinilai rendah atau tidak mirip. Meskipun tidak terbukti secara penuh, Canyon dan Hill (1997) cenderung mendukung "hipotesis mimikri", yaitu kemiripan visual daun antara benalu dan inangnya yang dipicu oleh upaya proteksi benalu dari herbivora, disebabkan oleh perbedaan fisiologis dan morfologi daun benalu dengan inangnya, seperti perbedaan kandungan air, nitrogen atau kandungan nutrisi yang lebih tinggi, kandungan senyawa antiherbivora, dan kekakuan daun. Namun konsep kemiripan visual daun antara benalu dan inangnya ini tidak terbukti berkorelasi sepenuhnya dengan faktor-faktor tersebut, artinya kedekatan morfologi tidak sepenuhnya mendukung asosiasi antara benalu dan inangnya. Glatzel dan Geils (2009) lebih 
menekankan interaksi antara benalu dan inangnya didominasi oleh faktor-faktor ekofisiologi, seperti pengendalian stomata dan transfer air, kandungan dan defisiensi mineral, dan kondisi inang, seperti kandungan fisik dan kimia kulit batang, mekanisme resistensi fisiologis, serta karakter-karakter adaptif dalam sebuah populasi. Bagaimanapun, korelasi antara kemiripan bentuk daun dengan faktorfaktor eko-fisiologis ini membutuhkan penelitian lebih lanjut.

Individu tanaman koleksi di Ecopark yang mengalami serangan benalu dalam studi ini tercatat sangat rendah, yaitu 14 individu koleksi $(0,2 \%$ dari total jumlah koleksi). Angka ini kontradiktif dengan Nickrent dan Musselman (2004) yang melaporkan dalam suatu studi lapang yang menggunakan 1.600 sampel pohon, $95 \%$ telah terjangkit benalu dari suku Loranthaceae. Rendahnya serangan ini diduga dipengaruhi oleh keterbatasan observasi lapang khususnya pada tajuk-tajuk bagian atas dan padat yang sulit terlihat saat observasi, serta kondisi tanaman koleksi yang sebagian besar masih relatif muda dan tidak terlalu tinggi (kurang dari $15 \mathrm{~m}$ ). Overton (1994), Aukema dan Martinez del Rio (2002) menyatakan frekuensi serangan benalu meningkat dengan bertambahnya tinggi pohon. Hal ini erat hubungannya dengan preferensi burung penyebar biji yang cenderung hinggap pada tangkai tajuk yang lebih tinggi. Pada studi ini, pohon inang Mangifera indica dan Mallotus paniculatus adalah dua inang yang memiliki tinggi 8 dan $10 \mathrm{~m}$ dan menunjukkan frekuensi serangan benalu yang tinggi dalam satu individu inang. Bagaimanapun terpadat kontradiksi dari hipotesis ini karena terdapat dua serangan benalu berjumlah 4 individu pada dua inang Wrightia religiosa berhabitus perdu. Hal ini menunjukkan adanya faktor ekofisiologi lain yang memengaruhi frekuensi serangan benalu selain tinggi tanaman. Kecenderungan frekuensi serangan benalu yang tinggi pada pohon-pohon dengan tajuk tinggi sementara ini dapat menjadi strategi bagi manajemen kebun untuk lebih memprioritaskan koleksi dengan tajuk yang tinggi dalam pengendalian populasi benalu.

Kasus serangan benalu pada koleksi perdu (1-2 $\mathrm{m})$ diduga salah satunya dipengaruhi oleh karakter buah inang.
Berdasarkan komunikasi pribadi pengelola kebun, Antidesma montanum dan Wrightia religiosa menghasilkan buah yang disukai oleh burung, sehingga perdu tersebut sering mendapat kunjungan burung yang kemungkinan besar juga menyebarkan biji benalu. Cara penyebaran benalu khususnya dari suku Loranthaceae banyak melibatkan burung (Aukema \& Martinez del Rio, 2002), sedangkan pada proses polinasi bunga banyak melibatkan burung untuk ukuran bunga yang besar dan serangga pada bunga berukuran kecil (Barlow, 1997; Nickrent \& Musselman, 2004). Biji suku Loranthaceae memiliki sticky viscin, yaitu lapisan lengket seperti lem yang persisten meskipun telah melalui saluran pencernaan. Saat buah dan biji dimakan oleh burung, biji menyebar bersama kotoran burung yang jatuh pada batang inang yang sesuai. Pesebaran biji benalu ini diduga erat hubungannya dengan preferensi tumbuhan yang dikunjungi oleh burung-burung pemakan buah benalu di suatu area. Preferensi tumbuhan yang dikunjungi oleh burung penyebar biji benalu di Ecopark, CSC-BG belum diketahui.

Karakter habitat koleksi perdu juga menjadi salah satu faktor pendukung serangan benalu. Koleksi perdu umumnya ditanam di area yang relatif terbuka. Nickrent dan Musselman (2004) menyatakan bahwa benalu mempunyai tingkat transpirasi yang lebih tinggi daripada inangnya, sehingga ada kecenderungan benalu memilih inang yang tumbuh di area terbuka atau tajuk teratas untuk lebih terekspos oleh sinar matahari. Kasus serangan pada pohon Mangifera indica dan Cerbera manghas menunjukkan bahwa kecenderungan benalu menjangkau bagian atas tajuk yang terekspos sinar matahari daripada tajuk bagian tengah atau bawah yang tertutup kanopi pohon. Hal inilah yang menjadi salah satu penghambat dalam inventarisasi dan pengendalian benalu oleh pelaksana teknis ke depan.

Interpretasi nilai indeks keanekaragaman Shanon Wiener $\left(\mathrm{H}^{\prime}\right)$ yang diperoleh jika nilai $\mathrm{H}^{\prime}$ semakin besar maka tingkat keanekaragaman semakin tinggi. Nilai $H^{\prime}=1,29$ yang diperoleh sebenarnya menunjukkan nilai yang rendah, namun dapat diklasifikasikan sebagai komunitas yang dalam kondisi stabil (Odum, 1994). Nilai indeks kemerataan (E') akan 
memberikan gambaran keseimbangan antara satu komunitas dengan komunitas lainnya (Magurran, 1988; Odum, 1994). Nilai kemerataan benalu yang tinggi di Ecopark, CSC-BG mengindikasikan bahwa penyebaran benalu secara umum relatif merata atau seimbang di seluruh area. Dengan mengabaikan batasan bioregion, nilai indeks kemerataan tersebut mengidikasikan bahwa pesebaran benalu di area Ecopark, CSC-BG tergolong merata di hampir semua bagian.

Dari analisis pola spasial, nilai indeks kekayaan jenis dan keanekaragaman jenis yang tinggi di beberapa bagian dari bioregion JawaBali, Sumatra, dan Kalimantan mengindikasikan bahwa area tersebut memiliki jumlah jenis benalu tertinggi dibandingkan area lain, dan sekaligus mengindikasikan bahwa jenis-jenis benalu tersebut terdistribusi lebih merata pada area tersebut. Didukung oleh konfirmasi data hasil observasi, empat jenis benalu atau sebagian besar jenis benalu seharusnya ditemukan pada bioregion tersebut. Selain itu, hasil analisis menunjukkan pada beberapa bagian bioregion Jawa-Bali, Kalimantan, Sulawesi, Papua, Nusa Tenggara dan Blok 1 akan didominasi oleh keberadaan salah satu atau sebagian kecil saja dari jenis benalu. Hipotesis ini kontradiktif dengan kenyataan di lapang bahwa tidak terdapat serangan benalu pada bioregion Sulawesi, Maluku dan Nusa Tenggara. Hipotesis hasil analisis pola spasial mengabaikan batasan bioregion dan menyamaratakan kondisi di seluruh bagian Ecopark, padahal dari pengamatan visual, jumlah tanaman koleksi atau dalam hal ini jumlah inang atau tanaman berpotensi inang di ketiga bioregion tersebut jauh lebih sedikit dibandingkan bioregion yang lain, sehingga distribusi dan pertumbuhan komunitas benalu di bioregion tersebut tidak akan secepat bioregion lain. Besar kemungkinan kepadatan tanaman koleksi dalam suatu area akan memengaruhi pertumbuhan komunitas benalu dan distribusinya, karena kepadatan tanaman koleksi ini akan memengaruhi jumlah tanaman berpotensi inang dan tutupan tajuk atau kerapatan kanopi. Bagaimanapun, hasil analisis pola spasial ini bisa menjadi prediksi di masa depan mengingat tidak ada batasan fisik antara bioregion dan jumlah tanaman koleksi yang mengisi masing-masing bioregion akan terus meningkat. Untuk saat ini, informasi tersebut dapat menjadi landasan ilmiah pihak pengelola untuk melakukan pengendalian benalu secara umum meliputi seluruh area Ecopark CSC-BG, dengan memprioritaskan bioregion Jawa-Bali, Sumatra dan Kalimantan.

Pengendalian komunitas benalu pada tanaman koleksi di kawasan konservasi ex situ seperti Ecopark CSC-BG memerlukan landasan ilmiah yang kuat dan tindakan yang tepat mengingat koleksi tumbuhan di Ecopark CSC-BG memiliki nilai sejarah, ilmiah, ekonomis, dan ekologis yang tinggi. Jika komunitas benalu dibiarkan tanpa ada kontrol, maka kelimpahan dan tingkat persebaran benalu akan semakin tinggi atau invasif dan menekan perkembangan koleksi tersebut. Saat observasi di lapang, sebagian besar kondisi inang yang terserang benalu masih relatif baik, namun kondisi ini dapat memburuk dengan meningkatnya ukuran individu benalu atau jumlah individu benalu dalam satu inang. Kondisi buruk ditunjukkan pada Arthocarpus sp., dengan kondisi pohon tanpa daun, tajuk atas dipenuhi oleh daun benalu, batang pohon yang tinggi dan kecil, serta kondisi benalunya sendiri yang mengalami klorosis. Diduga tanaman koleksi tersebut akan segera mati dalam waktu dekat. Teknik pemeliharaan koleksi dari benalu yang paling efektif yaitu dengan menggunakan teknik sederhana dengan pemangkasan cabang/ranting yang terserang benalu secara dini (Pitojo, 1996). Teknik tersebut juga dirasa tepat jika diterapkan di Ecopark CSC-BG mengingat dimana kondisi tanaman koleksi yang relatif masih muda.

\section{SIMPULAN DAN SARAN}

Terdapat empat jenis benalu yang ditemukan pada koleksi tanaman Ecopark CSC-BG, yaitu Dendrophthoe pentandra, Dendrophthoe sp., Scurrula atropurpurea, dan Macrosolen cochinchinensis. Beberapa faktor ekofisiologi yang disarankan untuk diperhatikan dalam distribusi benalu dan upaya pengendalian benalu di Ecopark CSC-BG adalah tinggi inang atau tanaman koleksi, ekspos cahaya pada tajuk bagian atas inang, kepadatan tanaman koleksi, keterbukaan atau ekspos cahaya matahari pada habitat. Secara umum distribusi benalu relatif merata di 
seluruh area Ecopark CSC-BG, dengan konsentrasi kekayaan jenis pada bioregion Jawa-Bali, Kalimantan dan Sumatra. Upaya dini dalam pemeliharaan koleksi tanaman yang perlu dilakukan oleh pihak manajemen meliputi pemangkasan ringan tajuk yang terserang, diikuti oleh sosialisasi jenis-jenis benalu di lingkungan Ecopark CSC-BG, karakter habitus dan habitat tanaman inang yang rentan terhadap serangan benalu, dan bioregion-bioregion prioritas kepada petugas lapang.

\section{UCAPAN TERIMA KASIH}

Penulis mengucapkan terima kasih kepada Kepala Pusat Penelitian Konservasi dan Kebun Raya-LIPI tahun 2016 atas izin penelitian di kawasan Ecopark, CSC-BG, Pengawas Ecopark CSC-BG tahun 2016, Bapak Mahatma Gandhi, dan Bapak Junaedi yang telah membantu dalam teknis pengambilan data. Kami juga mengucapkan terima kasih kepada rekan-rekan Kelompok 1 DJFP 2016, Satrio Herbirowo, Dita Insiyanda, Nadya Larasati, Artha Simbolon, Eka M. Handayani, Budiman P. A. Rohman, Widya Ningrum, Ilham Arisbaya, dan Ketut Wirtayasa untuk dukungan ide, tenaga dan pemikiran.

\section{REFERENSI}

Ariati, S. R., Astuti, R. S., \& Ruspandi. (2018). An alphabetical list of plant species cultivated in the Ecopark Cibinong Science Center and Botanic Gardens. Bogor: Center for Plant Conservation Botanic Gardens, LIPI.

Atsatt, P. R. (1983). Mistletoe leaf shape: A host morphogen hypothesis. In D. M. Calder \& P. Bernhardt (Eds). The Biology of Mistletoes (pp. 259-275). Sydney: Academic Press.

Aukema, J. E., \& Martinez del Rio, C. (2002). Variation in mistletoe seed deposition: Effects of intra- and interspecific host characteristics. Ecography, 25(2), 139144.

Backer, C. A., \& Bakhuizen van den Brink, R. C. Jr. (1965). Flora of Java II. Netherlands: Wolters- Noordhoff N.V.

Barlow, B. A. (1997). Loranthaceae. In C. Kalkman, D. W. Kirkup, H. P. Nooteboom, P. F. Stevens, \& W. J. J. O. de Wilde (Eds.), Flora Malesiana. Ser. (pp. 209-401). Leiden, Netherlands: Rijksherbarium, Hortus Botanicus.

Barlow, B. A., \& Wiens, D. (1977). Hostparasite resemblance in Australian mistletoes: The case for cryptic mimicry. Evolution, 31(1), 69-84.

Boerdeaux, C. Z. (2015). Keanekaragaman lumut kerak sebagai bioindikator kualitas udara di Kebun Raya Cibodas, Kebun Raya Bogor, dan Ecopark-LIPI Cibinong (Skripsi sarjana). Departemen Konservasi Sumberdaya Hutan dan Ekowisata, Fakultas Kehutanan, Institut Pertanian Bogor, Bogor, Indonesia.

Canyon, D. V., \& Hill, C. J. (1997). Mistletoehost resemblance: A study of herbivory, nitrogen and moisture in two Australian mistletoes and their host trees. Australian Journal of Ecology, 22(4), 395-403.

Chao, A. (2005). Species richness estimation. In C. B. Balakrishnan \& B. Vidakovi (Eds), Encyclopedia of statistical sciences (pp 7909-7916). New York, US: Wiley

Damayanto, I. P. G. P., Mulyani, S., \& Wahidah, B. F. (2019). Inventarisasi, kunci identifikasi, pemetaan, dan rekomendasi pengelolaan jenis-jenis bambu di Ecology Park, Pusat Konservasi Tumbuhan, Kebun RayaLIPI, Kabupaten Bogor, Jawa Barat. Jurnal Arsitektur Lansekap, 5(1)114-124.

Ehleringer, J. R., Ullmann, I., Lange, O. L., Fahquhar, G. D., Cowan, I. R., Schulze, E. D., \& Ziegler, H. (1986). Mistletoe: A hypothesis concerning morphological and chemical avoidance of herbivory. Oecologia, 70(2), 234-237.

Glatzel, G., \& Geils, B. W. (2009). Mistletoe ecophysiology: Host-parasite interaction. Botany, 87(1), 10-15

Hidayati, N., Mansur, M., \& Juhaeti, T. (2013). Variasi serapan karbondioksida (CO2) jenis-jenis pohon di "Ecopark" Cibinong dan kaitannya dengan potensi mitigasi gas rumah kaca. Buletin Kebun Raya, 16(1), 38-50.

Hijmans, R., Cruz, M., Rojas, E., \& Guarino, L (2001). DIVA-GIS, version 1.4. A geographic information system for the management and analysis of genetic 
resource data. Lima: International Potato Center and International Plant Genetic Resource Institute.

Huaxing, Q., Hua-hsing, C., Hua-xing, K., \& Gilbert, M. G. (2003). Loranthaceae. In Z. Wu \& P. Raven (Eds.), Flora of China 5 (pp. 220-239). Beijing, RRT: Missouri Botanical Garden Press.

Imron, H. M. B., Chodiq, A., \& Amas. (2016). Mengenal lebih dekat Cibinong Science Bogor-Botanical Garden (CSC-BG). Bogor: Lembaga Ilmu Pengetahuan Indonesia, LIPI.

Kintamani, E., Yulizah., \& Rahajoe, J. S. (2017). Input hara dari nekromasa pada ekosistem buatan Sumatra dan Jawa di Ecopark, Cibinong Science Center. In A. Agustien, Syaifullah, R. Pitopang, Nurainas, S. Ilyas, \& R. Kurniawan (Ed.), Implementasi kajian biodiversitas dalam upaya pengelolaan lingkungan dan ekowisata. Prosiding Semnas Biodiversitas dan Ekologi Tropika Indonesia Ke-4 dan Kongres Penggalang Taksonomi Tumbuhan Indonesia Ke-12 (pp. 161-169). Padang, Indonesia.

Magurran, A. E. (1988). Ecological diversity and its measurement. New Jersey (US): Princeton University Press.

Muttaqin, Z., Hartantri, H., Meiganati, K. B., \& Hidayat, I. (2019, September 10-11). Identification of pest and disease in The Plant Conservation Center-Bogor Botanical Garden (PKT-KRB) Ecological Park Cibinong, Bogor, West Java, Indonesia. Paper presented at IOP Conference Series: Earth and Environmental Science, The 2nd International Conference Silviculture: Forest Reaserach and Innovation for Sustainable Development, Bogor, Indonesia. Retrieved from https://iopscience.iop.org/article/10.1088 /1755-1315/394/1/012002

Nafar, S., \& Gunawan, A. (2017). Ecological design of fernery based on bioregion classification system in Ecopark Cibinong Science Center Botanic Gardens, Indonesia. IOP Conference Series: Earth and Environmental Science, 91 (1) 1-7.
Nickrent, D. L., \& Musselman, L. J. (2004). Introduction to parasitic flowering plants. The Plant health instructor, 13(6), 300-315.

Nickrent, D. L. (2002). Parasitic plants of the world. In J. A. L. Saez, P. Catalan, \& L. Saez (Eds.), Plantas parasitas de la Peninsula Iberica Balaeres (pp. 7-27). Madrid, Spanyol: Mundi-Prensa Libros, S.A.

Nooteboom, H. P., de Wilde, W. J. J. O., Kirkup, D.W., Stevens, P. F., Coode, M. J. E., \& Saw, L. G. (2016). Loranthaceae: Flora Malesiana data portal. (2020, March 20). Retrieved from http://portal.cybertaxonomy.org/floramalesiana/cdm_dataportal/taxon/ad82e4 5a-8bff-4ea0-85cf-789168c29e14

Noviady, I., \& Rivai, R. R. (2015, June 13). Identifikasi kondisi kesehatan pohon peneduh di kawasan Ecopark, Cibinong Science Center-Botanic Gardens. Paper presented at Prosiding Seminar Nasional Masyarat Biodiversitas Indonesia, Bandung, Indonesia. Retrieved from https://www.researchgate.net/publication /300559314_Identifikasi_kondisi_keseha tan_pohon_peneduh_di_kawasan_Ecopa rk_Cibinong_Science_Center

Odum, E. P. (1994). Dasar-dasar ekologi. (T. Samingan, Terjemahan). Yogyakarta: UGM Press.

Overton, J. M. (1994). Dispersal and infection in mistletoe metapopulations. Journal of Ecology, 82(4), 711-723.

Pitojo, S., (1996). Benalu hortikultura pengendalian dan pemanfaatan. Ungaran: Trubus Agriwidya.

Press, M. C., \& Phoenix, G. K. (2005). Impacts of parasitic plants on natural communities. New phytologist, 166(3), 737-751.

Putri, E. K., \& Chikmawati, T. (2015). Leaf flushing as taxonomy evidence of some Diospyros species. Floribunda, 5(2), 3147.

Quattrocchi, U. (2012). CRC world dictionary of medicinal and poisonous plants, common names, scientific names, eponyms, synonyms, and etymology. Florida: CRC Press, Taylor \& Francis Group. 
Quested, H. M. (2008). Parasitic plantsimpacts on nutrient cycling. Plant and Soil, 311(1-2), 269-272.

Rifai, M., \& Puryadi, D. (2008). Glosarium biologi. Jakarta: Pusat Bahasa Departemen Pendidikan Nasional.

Rist, L., Uma, S. R., \& Ghazoul, J. (2011). The spatial distribution of mistletoe in a Southern Indian Tropical Forest at multiple scales. Biotropica, 43(1), 50-57.

Rugayah., Widjaja, E. A., \& Praptiwi. (2004). Pedoman pengumpulan data keanekaragaman flora. Bogor: Pusat Penelitian Biologi, LIPI.

Stearn, W. T. (2004). Botanical latin. North America: Timber Press, Inc.

Sunaryo, S. (1998). Identifikasi kerusakan kerusakan tanaman inang oleh parasit Dendrophthoe pentandra (L.) Miq. (Loranthaceae): Sebuah studi kasus di Tahura Bengkulu. Berita Biologi, 4(2-3), 80-85.
Sunaryo, S., Rachman, E., \& Uji, T. (2006). Kerusakan morfologi tanaman koleksi Kebun Raya Purwodadi oleh benalu (Loranthaceae dan Viscaceae). Berita Biologi, 8(2), 129-139.

Sunaryo, \& Uji, T., (2010). Keanekaragaman jenis benalu pemarasit pada tanaman Di Kebun Raya Baturraden dan sekitarnya. Jurnal Teknologi Lingkungan, 11(2), 205-211.

Uji, T., Sunaryo., \& Rachman, E. (2006). Keanekaragaman jenis benalu parasit pada tanaman koleksi di Kebun Raya Purwodadi, Jawa Timur. Jurnal Teknologi Lingkungan Edisi Khusus "Hari Lingkungan Hidup",2006 223-231.

Uji, T., Sunaryo., \& Rachman, E. (2007). Keanekaragaman jenis benalu parasit pada tanaman koleksi di Kebun Raya Eka Karya, Bali. Berkala Penelitian Hayati Journal of Biological Researches, 13(1), 1-5. 